\title{
EVALUATION OF EFFICIENCY OF FUNDRAISING ACTIVITIES OF SMALL CHARITABLE ORGANIZATIONS OF UKRAINE
}

\author{
Oleh Vysochan ${ }^{1}$, Olha Vysochan ${ }^{2}$, Nataliia Lytvynenko ${ }^{3}$, Vasyl Hyk ${ }^{4}$ \\ ${ }^{1}$ Doctor of Science in Economics, Professor, Lviv Polytechnic National University, \\ Bandery St. 12, Lviv, Ukraine. Phone Number+380973078178. E-mail: Oleh.S.Vysochan@lpnu.ua \\ ${ }^{2}$ Ph. D. in Economics, Associated Professor, Lviv Polytechnic National University, \\ Bandery St. 12, Lviv, Ukraine. Phone Number+380973340787. E-mail: Olha.O.Vysochan@lpnu.ua \\ ${ }^{3}$ Ph. D. in Economics, Associated Professor, Lviv Polytechnic National University, \\ Bandery St. 12, Lviv, Ukraine. Phone Number +380689183894. E-mail: Nataliia.O.Lytvynenko@lpnu.ua \\ ${ }^{4}$ Ph. D. in Economics, Associated Professor, Lviv Polytechnic National University, \\ Bandery St. 12, Lviv, Ukraine. Phone Number+380976129763. E-mail:Vasyl.V.Hyk@lpnu.ua
}

Received 2612 2020; Accepted 01032021

\begin{abstract}
The paper describes the basic indicators of financial efficiency of fundraising activities, such as net proceeds from fundraising, return on fundraising costs, profitability of fundraising, the share of fundraising costs, the dependency ratio, average contributions, revenues received per unit of requests, as well as indicators component of fundraising activities of a charitable organization indirectly - the number of appeals of the charitable organization to potential donors, the number of positive feedback received from potential donors, the share of positive feedback, growth in the number of donors, growth in the number of new donors, return index. The use of aggregate indicators to calculate the financial efficiency of fundraising activities of a charitable organization is proposed: efficiency ratio based on net income of the donor, efficiency ratio based on willingness to donate, efficiency ratio based on the implementation of the revenue plan. The relative efficiency of fundraising activities of small charitable organizations of Ukraine in 2019 was assessed according to the DEA methodology.
\end{abstract}

Key words: charitable organizations, non-budgetary non-profit organizations, DEA-analysis, financial efficiency, fundraising.

JEL Codes: L31, C14.

\section{Introduction and review of literature}

Philanthropic aspirations of people, realized in the form of charity, are a powerful means of solving social problems of mankind. The state increasingly delegates part of its powers related to the support of education, culture, development of social security, etc. to non-budgetary non-profit organizations (hereinafter - NNO). Such a partnership is designed to increase the efficiency of the social and humanitarian sphere in the country

The catalyst for positive institutional changes in the economy of the non-profit sector of Ukraine is not only an increase in the number of charitable formations, but also an increase in the efficiency of their activities, which directly depends on the amount of funds raised and their further rational use. Finding and attracting external sources of funding, or fundraising, is a critical part of any charity's work. The activities of the latter can be considered efficient only if the successful implementation of goals in the fundraising field in parallel with the economical use of funds raised for this purpose.

Thus, the establishment and analysis of the efficiency of fundraising activities of charitable organizations is a partial task of the

Copyright (C) 2021 Author(s), published by Vytautas Magnus University. This is an open access article distributed under the terms of the Creative Commons Attribution Non-Commercial 4.0 (CC BY-NC 4.0) license, which permits unrestricted use, distribution, and reproduction in any medium provided the original author and source are credited. The material cannot be used for commercial purposes. 
overall assessment of the efficiency of their financial activities and is an important problem in the field of financial management of NNO, which requires proper theoretical and applied solutions. Over the past few decades, a number of leading economists around the world have sought to address key governance issues in the nonprofit sector, including identifying and sustaining the long-term efficiency of charities. These are, in particular, both theoretical studies on the definition and classification of the efficiency of NNO, and empirical research to establish its specific values.

Robert D. Herman and David O. Renz (2004) distinguish 9 elements of organizational efficiency of a non-profit organization: financial management; fundraising; program implementation; Public Relations; cooperation with the community; work with volunteers; human resource management; management relations; senior management of the organization.

Eyup A. Taisir and Nurgul K. Taisir (2012) such measurements are summarized by six: the efficiency of senior management; efficiency of managers; resource efficiency; financial efficiency; environmental efficiency; software efficiency.

The results of fundraising activities, the authors consider a measure of the efficiency of managers. Closer to the positioning of individual elements of the operating cycle of the organization is the classification proposed by Mark J. Epstein and Warren F. McFarlan (2011): administrative efficiency; software efficiency; fundraising efficiency; assessment of other financial activities.

In Ukraine, the issues raised in the article are in the focus of research by the following scientists: Buzduhan Ya.M. (2011), Hudz A.O. (2019), Ometsinska M.V. (2010), Pasichnichenko S.V. (2014), Povstyn O.V. (2014), Rodchenko V.B. and Serohina D.O. (2014), Serbyn R.A. (2015), Vysochan et al. (2020) and others.

The purpose of the article is a theoretical substantiation of the methodology for assessing the financial efficiency of charitable organizations and its practical implementation in the field of small charity in Ukraine by means of DEA-analysis.

\section{Methodology / approach}

To solve the problem of establishing the relative efficiency of organizations, taking into account the various indicators in different units of measurement that characterize it, it is convenient to use the method of Data Environment Analysis (table 1).

Table 1. Characteristics of the Data Environment Analysis (DEA) method (developed by authors)

\begin{tabular}{|c|c|c|}
\hline Sign & Characteristic & Comment \\
\hline Purpose of use & $\begin{array}{l}\text { Measuring the efficiency of functioning of } \\
\text { each (Decision Making Units, DMU) from a } \\
\text { predefined set }\end{array}$ & $\begin{array}{l}\text { DMUs must have common characteristics within a specific } \\
\text { set, but their positioning as an object of analysis is quite } \\
\text { flexible - from the decision maker to individual countries }\end{array}$ \\
\hline $\begin{array}{l}\text { Disposition among } \\
\text { the methods of } \\
\text { mathematical } \\
\text { statistics }\end{array}$ & Refers to non-parametric statistical methods & $\begin{array}{l}\text { Statistical analysis is performed without making a } \\
\text { preliminary assumption about the nature of the distribution } \\
\text { of the studied data }\end{array}$ \\
\hline Technology of use & $\begin{array}{l}\text { Solving the optimization problem by means } \\
\text { of linear programming }\end{array}$ & $\begin{array}{l}\text { Quantitative measure of efficiency for the objective function } \\
\text { is the maximum implementation of DMU products (outputs) } \\
\text { at a given number of resources (inputs) or minimization of } \\
\text { resources used at a given level of product output }\end{array}$ \\
\hline $\begin{array}{l}\text { The method of } \\
\text { determining the } \\
\text { efficiency }\end{array}$ & $\begin{array}{l}\text { Establish a capacity limit (efficiency limit) } \\
\text { based on the DMU with the highest scores. } \\
\text { All other DMUs are considered effective to } \\
\text { the extent that they are closer to the } \\
\text { established limit }\end{array}$ & $\begin{array}{l}\text { It is necessary to perform a pairwise comparison of each of } \\
\text { the DMU in terms of their "output-input" relationship in } \\
\text { order to obtain relative estimates of efficiency }\end{array}$ \\
\hline Advantage of use & Ability to install DMUs using best practices & $\begin{array}{l}\text { No need to build abstract statistical models allows DMU to } \\
\text { focus on best practices rather than averaged results, as in the } \\
\text { case of regression analysis }\end{array}$ \\
\hline
\end{tabular}




\section{sciendo}

\section{Management Theory and Studies for Rural Business and Infrastructure Development eISSN 2345-0355. 2021. Vol. 43. No. 1: 100-110 \\ Article DOI: https://doi.org/10.15544/mts.2021.09}

The study developed aggregate indicators based on a simplified model of fundraising activities, taking into account several key factors, and used the method of DEA-analysis to implement a nonparametric statistical approach to solving the problem of evaluating the efficiency of fundraising activities of small charities in Ukraine.

The source of data for the analysis was the tax reporting of charitable organizations, namely the Reports on the use of income (profits) of the non-profit organization for the 2019 tax year of small charitable organizations, published by the Ukrainian Forum of Philanthropists.

For the first time, DEA-analysis tools were used to compare the efficiency of fundraising of various charitable organizations in the non-profit sector of Ukraine's economy. The initial indicator was the income in the form of voluntary donations, the input - the number of staff and administrative and other costs of maintaining the organization.

The results of calculating the relative efficiency of fundraising activities of 20 small charitable organizations of Ukraine in 2019 according to the DEA method allowed to identify the leaders of the sector, as well as to develop recommendations for improving the efficiency of fundraising activities of outsiders.

\section{Results and discussions}

From the economic point of view, the efficiency of activities involves obtaining a positive financial result by attracting a minimum amount of resources. For non-profit $\mathrm{NNO}$, it is important to distinguish between social (the degree to which the goal of the activity is achieved through the implementation of specific projects) and financial (the quality of raising and using funds and other resources to achieve the goal). In this approach, the financial efficiency of a charitable organization is a function that depends on two values: the efficiency of raising funds (fundraising) and the efficiency of the use of funds (Fig. 1).

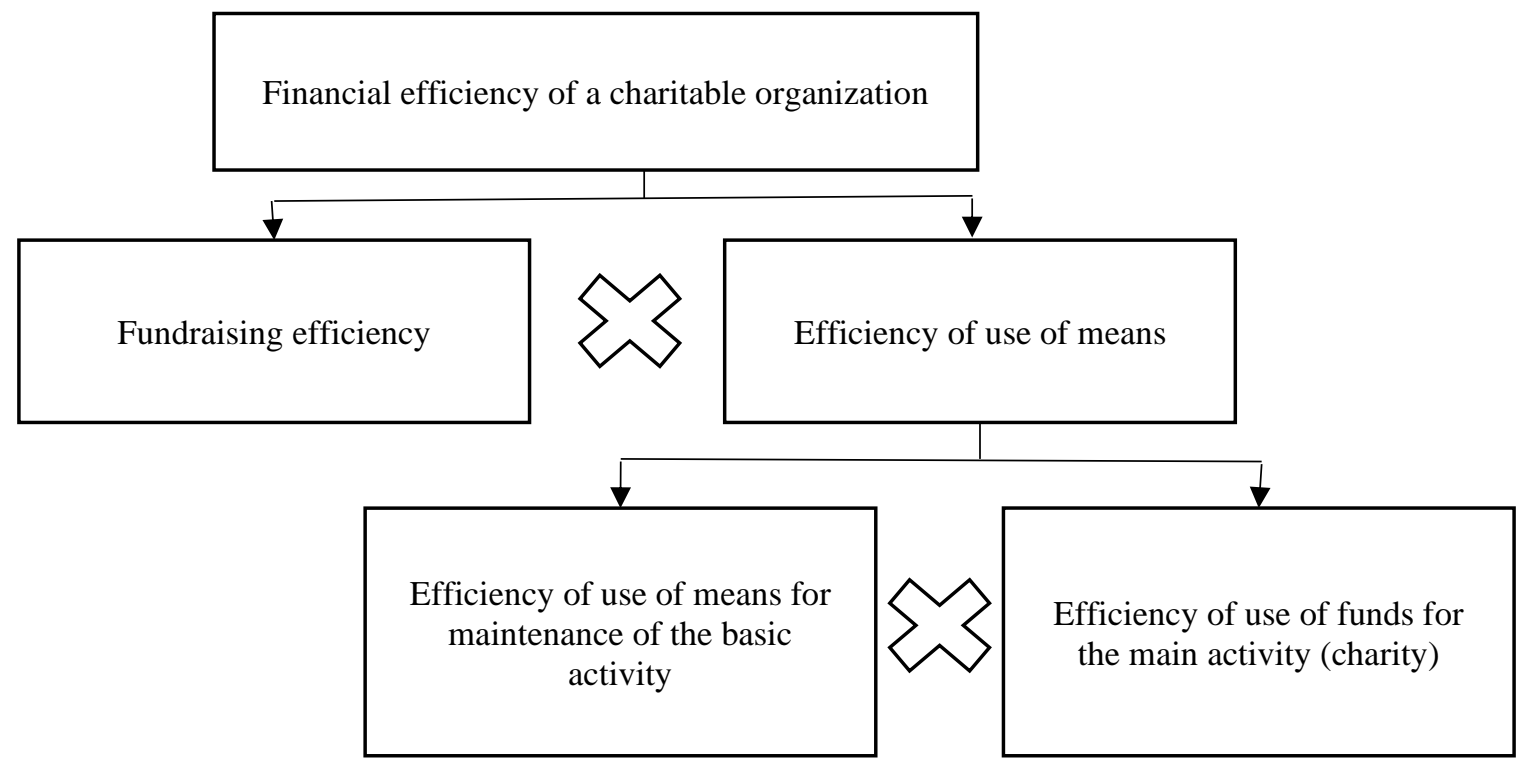

Figure 1. Model of calculation of financial efficiency of the charitable organization (developed by the authors )

Copyright (C) 2021. Published by Vytautas Magnus University. This is an open access article distributed under the terms of the Creative Commons Attribution Non-Commercial 4.0 (CC BY-NC 4.0) license, which permits unrestricted use, distribution, and reproduction in any medium provided the original author and source are credited. The material cannot be used for commercial purposes. 
The most difficult to analyze the first component - the efficiency of raising funds, due to the influence of a significant number of factors that have external and internal nature. In the work of David T. Yi. (2010) the influence of three main factors on the efficiency of fundraising is assessed: the size of the organization; state support; distribution of resources allocated for raising funds. In fact, there are many more such poorly structured factors. When assessing the financial efficiency of fundraising activities of a charitable organization, three different approaches can be used:

Approach 1. Financial efficiency is assessed on the basis of generalized values of a number of indicators that characterize various aspects of fundraising activities of a charitable organization.
Approach 2. The assessment of financial efficiency is based on one aggregate indicator, which is developed based on a simplified model of fundraising activities, taking into account several key factors.

Approach 3. Evaluation of financial efficiency is performed using non-parametric methods, such as DEA-analysis.

When using the first approach, a set of a number of parameters that characterize the fundraising activities of the organization is formed. For example, James M. Greenfield (1996) proposed the use of three basic (number of donors, income, fundraising costs) and six derivatives (donor share, average donation, net income, average donation, payback, turnover). Based on his publications and research of other scientists, we have summarized and characterized the efficiency of fundraising activities (Table 2).

Table 2. Quantitative partial indicators of financial efficiency of charitable organization fundraising activity (Source: summarized on the basis of (Greenfield J.M., 1996; Basova M.M., 2019; Grishchenko Iu.I., 2015) and supplemented by characteristics developed by the authors))

\begin{tabular}{|c|c|c|}
\hline Indicator, unit of measurement & Method of calculation & Source of information \\
\hline \multicolumn{3}{|c|}{ Indicators that directly characterize financial efficiency } \\
\hline $\begin{array}{l}\text { Net proceeds from fundraising, } \\
\text { thousand UAH }\end{array}$ & $\begin{array}{l}\text { The difference between the total amount of funds } \\
\text { raised and the total amount of fundraising costs }\end{array}$ & Synthetic financial accounting data \\
\hline Payback of fundraising costs, $\%$ & $\begin{array}{l}\text { The ratio of the total amount of funds raised to the } \\
\text { total cost of fundraising }\end{array}$ & $\begin{array}{l}\text { Synthetic financial accounting data, } \\
\text { calculation }\end{array}$ \\
\hline Profitability of fundraising, $\%$ & $\begin{array}{l}\text { The ratio of net proceeds from fundraising to the } \\
\text { total amount of borrowed funds }\end{array}$ & $\begin{array}{l}\text { Synthetic financial accounting data, } \\
\text { calculation }\end{array}$ \\
\hline Shar & $\begin{array}{l}\text { ndraising costs in the total costs of } \\
\text { n }\end{array}$ & $\begin{array}{l}\text { Synthetic financial accounting data, } \\
\text { calculation }\end{array}$ \\
\hline Depend & $\begin{array}{l}\text { funds raised from the five largest } \\
\text { ed by the cost of the organization }\end{array}$ & $\begin{array}{l}\text { Analytical accounting data, } \\
\text { calculation }\end{array}$ \\
\hline $\begin{array}{l}\text { Average contributions, thousand UAH } \\
\text { / person }\end{array}$ & contributions received & $\begin{array}{l}\text { Analytical accounting data, query } \\
\text { information, calculation }\end{array}$ \\
\hline $\begin{array}{l}\text { Receipts received per unit of requests, } \\
\text { thousand UAH / request }\end{array}$ & $\begin{array}{l}\text { The amount of funds raised per one appeal of the } \\
\text { charity to potential donors }\end{array}$ & data, query \\
\hline \multicolumn{3}{|c|}{ Indicators that indirectly characterize financial efficiency } \\
\hline $\begin{array}{l}\text { The number of appeals of the } \\
\text { charitable organization to potential } \\
\text { donors, inquiries }\end{array}$ & $\begin{array}{l}\text { The number of sent proposals for donations for } \\
\text { specific purposes }\end{array}$ & $\mathrm{A}_{1}$ \\
\hline $\begin{array}{l}\text { e feedback received } \\
\text { lors, inquiries }\end{array}$ & $\begin{array}{l}\text { Number of proposals that inte } \\
\text { donors }\end{array}$ & \\
\hline $\begin{array}{l}\text { Proportion of positive feedback, } \\
\text { inquiries, } \%\end{array}$ & $\begin{array}{l}\text { The share of positive feedback received from the } \\
\text { total number of appeals to potential donors }\end{array}$ & ation \\
\hline $\begin{array}{l}\text { Increasing the number of donors, } \\
\text { individuals }\end{array}$ & $\begin{array}{l}\text { Dynamics of donor involvement during a certain } \\
\text { period of time compared to the previous reporting } \\
\text { period }\end{array}$ & $\begin{array}{l}\text { Registers, request information, } \\
\text { calculation }\end{array}$ \\
\hline ig the numbe & $\begin{array}{l}\text { Dynamics of attracting donors who make } \\
\text { donations for the first time }\end{array}$ & $\begin{array}{l}\text { Registers, request information, } \\
\text { calculation }\end{array}$ \\
\hline Return index, \% & $\begin{array}{l}\text { Proportion of donors who make donations on a } \\
\text { regular basis from the total number of donors }\end{array}$ & $\begin{array}{l}\text { Registers, request information, } \\
\text { calculation }\end{array}$ \\
\hline
\end{tabular}




\title{
sciendo
}

\author{
Management Theory and Studies for Rural Business and Infrastructure Development \\ eISSN 2345-0355. 2021. Vol. 43. No. 1: 100-110 \\ Article DOI: https://doi.org/10.15544/mts.2021.09
}

Data for the calculation of the first group of indicators can be obtained from the accounting system of the organization. At the same time, many critics point to a number of reasons that prevent them from being used to assess the financial efficiency of a charity's fundraising activities. Arthur Brooks (2004) draws attention to three of them:

1) the averaging of indicators does not allow to obtain information in terms of operations carried out by the organization;

2) disregard for external factors that are beyond the control of the organization. To solve this problem, the author recommends the use of adjusted performance indicators (Adjusted Performance Measures), calculated using a regression model with a random variable;
3) gaps in the internal accounting standards for fundraising activities of the organization. In particular, the author points out the difficulties in objectively determining the share of costs related to fundraising.

Indirect indicators do not have a direct impact on the efficiency of fundraising (for example, the positive dynamics of the number of appeals of a charitable organization to potential donors does not indicate a real increase in funds raised), but their growth is the basis for its stability.

The above indicators can be calculated with different levels of detail: in general, the organization, in terms of individual programs.

The second approach involves the calculation of a summary indicator, possible variants of which are given in table 3 .

\section{Table 3. General indicators of financial efficiency of fundraising activity of charitable organization (Source: developed by the authors)}

\begin{tabular}{|c|c|c|c|c|}
\hline $\begin{array}{c}\text { Indicator, unit of } \\
\text { measurement }\end{array}$ & Characteristic & Advantages of use & Disadvantages of use & $\begin{array}{c}\text { Source of } \\
\text { information }\end{array}$ \\
\hline $\begin{array}{l}\text { Efficiency ratio based } \\
\text { on the donor's net } \\
\text { income, } \%\end{array}$ & $\begin{array}{l}\text { The ratio of total } \\
\text { revenues to the aggregate } \\
\text { amount of net income } \\
\text { (income less taxes and } \\
\text { mandatory payments, } \\
\text { which could theoretically } \\
\text { be used as voluntary } \\
\text { donations) of potential } \\
\text { donors }\end{array}$ & \begin{tabular}{|l|} 
The indicator \\
characterizes the \\
possibilities of \\
developing socially \\
responsible interaction \\
between the subjects of \\
public relations
\end{tabular} & $\begin{array}{l}\text { Difficulty of practical } \\
\text { use due to the high } \\
\text { level of confidentiality } \\
\text { of information on the } \\
\text { income of potential } \\
\text { donors }\end{array}$ & $\begin{array}{l}\text { Synthetic } \\
\text { accounting data, } \\
\text { donor surveys, } \\
\text { official } \\
\text { declaration data }\end{array}$ \\
\hline $\begin{array}{l}\text { Efficiency ratio based } \\
\text { on donation readiness, } \\
\%\end{array}$ & $\begin{array}{l}\text { The ratio of the total } \\
\text { amount of proceeds to the } \\
\text { amount of the estimated } \\
\text { financial readiness of } \\
\text { potential donors to make } \\
\text { donations }\end{array}$ & $\begin{array}{l}\text { The indicator } \\
\text { demonstrates the } \\
\text { potential for growth in } \\
\text { fundraising revenues }\end{array}$ & $\begin{array}{l}\text { The difficulty of } \\
\text { assessing the readiness } \\
\text { of donations due to the } \\
\text { subjectivity and } \\
\text { volatility of the latter }\end{array}$ & $\begin{array}{l}\text { Synthetic } \\
\text { accounting data, } \\
\text { donor surveys }\end{array}$ \\
\hline $\begin{array}{l}\text { Coefficient of } \\
\text { efficiency, based on the } \\
\text { implementation of the } \\
\text { revenue plan, \% }\end{array}$ & $\begin{array}{l}\text { The share of actually } \\
\text { received donor funds } \\
\text { from the planned budget } \\
\text { revenues }\end{array}$ & \begin{tabular}{|l|} 
Easy to use, \\
independent of the \\
reliability of external \\
sources of information
\end{tabular} & \begin{tabular}{|l|} 
Imperfection of existing \\
methods of forecasting \\
income from \\
fundraising activities
\end{tabular} & \begin{tabular}{|l} 
Synthetic \\
accounting data, \\
organization's \\
revenue budget
\end{tabular} \\
\hline
\end{tabular}

The logic of calculating the efficiency indicator based on the net income of the donor is to assume that a person's altruistic aspirations can be so great that, in theory, he can sacrifice all the income (minus a number of basic mandatory costs or related with livelihoods: taxes, utilities, food, tuition, etc.) for charity. In theory, the indicator makes it

Copyright (C) 2021 Author(s), published by Vytautas Magnus University. This is an open access article distributed under the terms of the Creative Commons Attribution Non-Commercial 4.0 (CC BY-NC 4.0) license, which permits unrestricted use, distribution, and reproduction in any medium provided the original author and source are credited. The material cannot be used for commercial purposes. 
possible to assess the possibilities and prospects of attracting additional funds from potential donors, taking into account the maximum propensity for philanthropy.

The problem in calculating the efficiency ratio based on donation readiness is the calculation of such a willingness of a potential donor, as it depends on a number of factors that are difficult to quantify. Laura Fredriks (2010) names six factors that are included in her socalled "readiness formula": awareness, interest, training, willingness to give money, financial situation, the right time to ask. Most of these factors have a strong qualitative component and a significant level of subjectivity in evaluation. At the same time, this approach makes it possible to assess the growth potential of borrowed funds with proper adjustment of the fundraising policy of the organization. The logic of the calculation is that if the donor was willing to donate a certain amount, but actually donated less money, the problem should be sought in the inefficient fundraising activities of the charity. For private charitable foundations with monodonary support, the efficiency ratio, based on the readiness to donate, is almost always equal to 1 or $100 \%$.

To establish specific thresholds, you can use the results of publicly available opinion polls, which are periodically conducted in Ukraine. For example, some results of a national survey on civic engagement, which was conducted in July-August 2020 as part of the Program to promote civic activity "Join!" (funded by the United States Agency for International Development (USAID) provide an opportunity to assess the readiness of Ukrainian citizens to donate (Table 4).

Table 4. Assessment of readiness for donations of citizens of Ukraine in 2020

(Developed author's on the basis of the results of a nationwide survey conducted within the framework of the program to promote public activity "Join!" (Help yourself, 2020). Sampling error - 2.2\%)

\begin{tabular}{|c|c|c|c|c|}
\hline \multirow[t]{2}{*}{$\begin{array}{l}\text { Categories of } \\
\text { respondents }\end{array}$} & \multirow{2}{*}{$\begin{array}{c}\text { Thresholds of } \\
\text { respondents' } \\
\text { readiness for charity }\end{array}$} & \multicolumn{2}{|c|}{$\begin{array}{c}\text { Distribution of respondents by } \\
\text { categories (in \%): }\end{array}$} & \multirow{2}{*}{$\begin{array}{l}\text { Financial assessment of } \\
\text { readiness for donations } \\
\text { (in UAH) per } 100 \text { donors }\end{array}$} \\
\hline & & $\begin{array}{c}\text { for all } \\
\text { categories }\end{array}$ & $\begin{array}{c}\text { for small and } \\
\text { medium donors }\end{array}$ & \\
\hline $\begin{array}{l}\text { Persons who do not } \\
\text { plan to make donations }\end{array}$ & $0 \mathrm{UAH}$ & 33 & - & - \\
\hline Small donors & $100 \mathrm{UAH}$ & 25 & 64 & 6400 \\
\hline Medium donors & $1000 \mathrm{UAH}$ & 14 & 36 & 36000 \\
\hline Large donors & $>1000 \mathrm{UAH}$ & 2 & - & - \\
\hline Regular donors & $\begin{array}{l}\text { Part of the income } \\
\text { received }\end{array}$ & 4 & - & - \\
\hline Undecided persons & Not installed & 23 & - & - \\
\hline \multicolumn{2}{|l|}{ Total } & 100 & 100 & 42400 \\
\hline
\end{tabular}

The processed data show that when calculating the efficiency ratio, based on the readiness for donations, the estimated volume of potential donations of UAH 42,400 / 100 donors (for individuals in the categories of small and medium donors) can be used as a baseline value. In the future, this value can be adjusted by the charity depending on its current state and prospects. The financial assessment of the readiness for donations of large donors should be calculated individually for each donor and taken into account separately when determining the financial efficiency of the fundraising activities of a charitable organization.

The efficiency ratio, based on the implementation of the revenue plan, is easy to calculate, and, at the same time, more reliable than the previous ones. Its main drawback is that non-fulfillment of the revenue plan may be due not so much to inefficient fundraising activities as to budget mistakes. The opposite statement is also true: a significant overfulfillment of the planned values of donor revenues may be the result of low budget performance, rather than the organization's use of efficient fundraising measures. At the same 


\title{
sciendo
}

\author{
Management Theory and Studies for Rural Business and Infrastructure Development \\ eISSN 2345-0355. 2021. Vol. 43. No. 1: 100-110 \\ Article DOI: https://doi.org/10.15544/mts.2021.09
}

time, the use of relevant tools and modern methods of implementing the budgetary mechanism of the organization is likely to help offset the negative impact of this shortcoming. In case of full implementation or overfulfillment of the revenue plan in the calculation of the overall financial efficiency of the charitable organization, the value of the efficiency ratio, based on the implementation of the revenue plan is taken at the level of 1 or $100 \%$.

Another well-known technology that can be used to assess the effectiveness of fundraising is the FEP (Fundraising Effectiveness Project) methodology, developed in 2006 by the Association of Fundraising Professionals in collaboration with the Center on Nonprofits and Philanthropy) at the Institute of Urbanism in Washington, DC, USA. The FEP methodology provides for the formation of the so-called "Growth-in-Giving, GiG Report" with the definition of the overall growth rate of donations. The methodology is based on the division of donors into 6 categories according to their impact on the income and expenses of the charity, each of which requires a special approach to fundraising management (Table $5)$.

Table 5. Categories of donors in the FEP concept (According to Levis, Williams, 2011)

\begin{tabular}{|l|l|l|}
\hline \multicolumn{1}{|c|}{$\begin{array}{c}\text { Category of donors by } \\
\text { revenues and expenditures }\end{array}$} & \multicolumn{1}{|c|}{ Characteristic } & $\begin{array}{c}\text { The purpose of the fundraising } \\
\text { strategy }\end{array}$ \\
\hline \multicolumn{3}{|c|}{ Lead to an increase in revenue } \\
\hline New & $\begin{array}{l}\text { Donors who have never made donations before } \\
\text { this year }\end{array}$ & $\begin{array}{l}\text { Increased revenue from new } \\
\text { donors }\end{array}$ \\
\hline Recaptured & $\begin{array}{l}\text { Donors who have started making donations } \\
\text { again this year }\end{array}$ & $\begin{array}{l}\text { Return of proceeds from previously } \\
\text { lost donors }\end{array}$ \\
\hline Upgraded & $\begin{array}{l}\text { Donors whose donations this year exceeded } \\
\text { the previous year }\end{array}$ & $\begin{array}{l}\text { Increased revenue from improved } \\
\text { donors }\end{array}$ \\
\hline \multicolumn{1}{|c|}{ Lead to an increase in costs } \\
\hline Downgraded & $\begin{array}{l}\text { Donors whose donations this year were less } \\
\text { than the previous year }\end{array}$ & $\begin{array}{l}\text { Avoid losses due to reduced donor } \\
\text { revenues }\end{array}$ \\
\hline Lapsed New & $\begin{array}{l}\text { Donors who were in the "New" category last } \\
\text { year, but did not make donations this year }\end{array}$ & $\begin{array}{l}\text { Avoid losses due to lack of } \\
\text { contributions from lost new donors }\end{array}$ \\
\hline Lapsed Repeat & $\begin{array}{l}\text { Other lost donors who made donations in } \\
\text { previous years, but stopped in the current }\end{array}$ & $\begin{array}{l}\text { Avoid losses due to lack of } \\
\text { contributions from other lost } \\
\text { donors }\end{array}$ \\
\hline
\end{tabular}

The total financial result from fundraising activities is calculated as the sum of income from the first three categories of donors minus the result of losses from the last three categories. The data in the final lines of the report are calculated based on the growth rate of income / loss (compared to the previous reporting period). The growth rate of net income / loss, as a result of the report, is calculated by comparing it with a similar indicator of the previous reporting period. This approach allows the charity's management to make decisions about the redistribution of resources to certain areas of fundraising activities, thus maximizing its efficiency.

The difference between net income and net loss can be used as an indicator of the

Copyright (C) 2021 Author(s), published by Vytautas Magnus University. This is an open access article distributed under the terms of the Creative Commons Attribution Non-Commercial 4.0 (CC BY-NC 4.0) license, which permits unrestricted use, distribution, and reproduction in any medium provided the original author and source are credited. The material cannot be used for commercial purposes. 
financial efficiency of fundraising activities using this method. In case of exceeding the first, the fundraising activities of the charity can be considered efficient, otherwise - no.The third approach involves the use of nonparametric methods of performance evaluation, the most common of which is DEA-analysis, which consists in a pairwise comparison of each individual resource (input) with each individual product (output) to obtain relative performance evaluations.

Peculiarities of using the DEA method in management are:

1) each decision-making unit (AU) is described by one final relative efficiency indicator;

2) specific ODA-specific improvement forecasts are based on best practices identified in other ATS;
3) an alternative approach with the refusal to develop abstract statistical models and draw conclusions based on regression and parametric analysis (Charnes et al., 1994).

In our case, the fundraising activities of charitable organizations that act as decisionmaking units (Decision Making Units, DMUs) are described by a set of input (Inputs) and output (Outputs) parameters. The input parameters of a charitable organization consist of human resources involved in the main activities, as well as funds spent on the maintenance of the organization, which are summarized in the indicator of administrative and other costs. The initial parameter represents the results of fundraising activities of the charitable organization, presented as income in the form of voluntary donations (Table 6).

Table 6. Sets of input and output parameters to solve the problem of evaluating the efficiency of fundraising activities of small charities in Ukraine using the DEA methodology

\begin{tabular}{|c|c|c|c|}
\hline \multirow[t]{2}{*}{ Name of the charity } & \multicolumn{2}{|r|}{ Inputs } & \multirow{2}{*}{$\begin{array}{c}\text { Outputs } \\
\text { Receipts in the form } \\
\text { of voluntary } \\
\text { donations, UAH }\end{array}$} \\
\hline & $\begin{array}{l}\text { Number of } \\
\text { employees, } \\
\text { pers. }\end{array}$ & $\begin{array}{l}\text { Administrative and other } \\
\text { expenses for the maintenance } \\
\text { of the organization, UAH }\end{array}$ & \\
\hline $\mathrm{CO}$ "CF "Kyiv" & 2 & 581895 & 5696515 \\
\hline CO "CF "Kolo" & 6 & 1654839 & 2246307 \\
\hline CO "Bright kids" & 2 & 72189 & 447258 \\
\hline CF "We give joy" & 4 & 1080988 & 1405976 \\
\hline CF "Kvitna" & 6 & 437524 & 2942409 \\
\hline CO "Ukrainian forum of philanthropists" & 2 & 690969 & 2591244 \\
\hline CO "CF "Svichado" & 4 & 289958 & 4212917 \\
\hline CO "Nechitaylo family foundation" & 6 & 620593 & 9931610 \\
\hline CO ICF "Everyone can" & 4 & 767451 & 1790162 \\
\hline CF "Blagomay" & 4 & 380269 & 8133900 \\
\hline CF "Pediatricians against cancer" & 3 & 242162 & 1215809 \\
\hline A-UCF "Down syndrome" & 8 & 302322 & 4811499 \\
\hline ICF "Life with a surplus" & 8 & 919628 & 8397251 \\
\hline "Old people" & 4 & 325103 & 1678430 \\
\hline CO "Berezani Community Foundation" & 1 & 51435 & 841293 \\
\hline $\mathrm{CO}$ "CF "Hope for life" & 3 & 17576 & 912526 \\
\hline ICF Dr. Bersenev & 1 & 93989 & 605353 \\
\hline $\begin{array}{l}\text { A-UCF "Assistance and development "Help } \\
\text { group" }\end{array}$ & 2 & 143975 & 939971 \\
\hline $\mathrm{CO}$ "CF "Community unity" & 1 & 94584 & 560731 \\
\hline CO "WBF "Ray of hope" & 3 & 7923 & 150182 \\
\hline
\end{tabular}

Source: summarized by the authors on the basis of the processed data of the Reports on the use of income (profits) of a non-profit organization for the 2019 tax year of small charitable organizations, published on the resource of the Ukrainian Forum of Philanthropists https://rating.ufb.org.ua/

Conventional abbreviations in the table: $\mathrm{CO}$ - Charitable organization, $\mathrm{CF}$ - Charitable foundation, A-UCF - AllUkrainian Charitable foundation, ICF - International Charitable foundation. 


\title{
sciendo
}

\author{
Management Theory and Studies for Rural Business and Infrastructure Development \\ eISSN 2345-0355. 2021. Vol. 43. No. 1: 100-110 \\ Article DOI: https://doi.org/10.15544/mts.2021.09
}

In the sample table 6 included 20 small charitable organizations of Ukraine, which provided open access to tax reporting in 2019. Criteria for classifying charitable organizations as small: the number of full-time employees - up to 10 people; the amount of attracted funding for the year - up to UAH 10 million. Achieving the maximum efficiency of fundraising activities of each specific charitable organization involves attracting more voluntary donations with minimal resource costs. DEA-analysis provides for the need to calculate the efficiency of individual decision-making units in relation to other organizations to determine the degree of

\begin{tabular}{|c|c|c|c|c|c|c|c|c|}
\hline $\begin{array}{l}\text { DMU } \\
\text { No. }\end{array}$ & DMU Name & $\begin{array}{l}\text { Input-Oriented } \\
\text { VRS Efficiency }\end{array}$ & \multicolumn{6}{|c|}{ Optimal Lambdas with Benchmarks } \\
\hline 1 & $\mathrm{CO}$ "CF "Kyiv" & 1,00000 & 1,000 & DMU1 & - & - & - & - \\
\hline 2 & CO "CF "Kolo" & 0,21490 & 0,289 & DMU1 & 0,711 & DMU15 & - & - \\
\hline 3 & CO "Bright kids" & 0,63259 & 0,867 & DMU15 & 0,133 & DMU20 & - & - \\
\hline 4 & CF "We give joy" & 0,27908 & 0,116 & DMU1 & 0,884 & DMU15 & - & - \\
\hline 5 & CF "Kvitna" & 0,32931 & 0,288 & DMU10 & 0,656 & DMU15 & 0,057 & DMU16 \\
\hline 6 & $\mathrm{CO}$ "Ukrainian forum of philanthropists" & 0,68021 & 0,360 & DMU1 & 0,640 & DMU15 & - & - \\
\hline 7 & CO "CF "Svichado" & 0,68008 & 0,461 & DMU10 & 0,370 & DMU15 & 0,169 & DMU16 \\
\hline 8 & CO "Nechitaylo family foundation" & 1,00000 & 1,000 & DMU8 & - & - & - & - \\
\hline 9 & CO ICF "Everyone can" & 0,29886 & 0,195 & DMU1 & 0,805 & DMU15 & - & - \\
\hline 10 & CF "Blagomay" & 1,00000 & 1,000 & DMU10 & - & - & - & - \\
\hline 11 & CF "Pediatricians against cancer" & 0,36363 & 0,063 & DMU1 & 0,009 & DMU10 & 0,927 & DMU15 \\
\hline 12 & A-UCF "Down syndrome" & 0,70588 & 0,540 & DMU10 & 0,460 & DMU16 & - & - \\
\hline 13 & ICF "Life with a surplus" & 0,53662 & 0,146 & DMU8 & 0,854 & DMU10 & - & - \\
\hline 14 & "Old people" & 0,32334 & 0,051 & DMU1 & 0,081 & DMU10 & 0,868 & DMU15 \\
\hline 15 & CO "Berezani Community Foundation" & 1,00000 & 1,000 & DMU15 & - & - & - & - \\
\hline 16 & $\mathrm{CO}$ "CF "Hope for life" & 1,00000 & 1,000 & DMU16 & - & - & - & - \\
\hline 17 & ICF Dr. Bersenev & 1,00000 & 1,000 & DMU15 & - & - & - & - \\
\hline 18 & $\begin{array}{l}\text { A-UCF "Assistance and development "Help } \\
\text { group” }\end{array}$ & 0,51016 & 0,020 & DMU1 & 0,980 & DMU15 & - & - \\
\hline 19 & $\mathrm{CO}$ "CF "Community unity" & 1,00000 & 1,000 & DMU15 & - & - & - & - \\
\hline 20 & CO "WBF "Ray of hope" & 1,00000 & 1,000 & DMU20 & - & - & - & - \\
\hline
\end{tabular}

achievement of the goal on the criteria of minimizing human resources, administrative and other costs of maintenance and maximizing revenues in the form of voluntary donations. Leaders are those charitable organizations that, with a small number of employees and low maintenance costs, attract the maximum amount of voluntary donations. The rest of the organizations will be outsiders and, subject to further stability of external revenues, should optimize the number of staff and / or maintenance costs, focusing on the practice of fundraising leading organizations (Table 7).

\section{Table 7. The results of calculating the relative efficiency of fundraising activities of small
table organizations in Ukraine in 2019 according to the DEA (Source: calculated by the \\ Table 7. The results of calculating the relative efficiency of fundraising activities of small
charitable organizations in Ukraine in 2019 according to the DEA (Source: calculated by the authors using the tools of DEA-analysis (VRS input-oriented model) based on the input data of table)}


The coefficient of relative efficiency presented in table 7, demonstrates how efficiently a charitable organization uses human resources and funds for its maintenance in relation to all other organizations. If the efficiency ratio is equal to one, then the organization belongs to the leaders (efficient unit), if less than one, - outsiders (inefficient unit). For each outsider, a hypothetical leader organization (ideal) is selected, which is formed by a combination of parameter values of existing leaders (2-3 for each outsider). Reference charities that are involved in building the ideal combination for the outsider are benchmarks. The contributions of such organizations are ideally characterized by lambda coefficients (Table 7). To be efficient, a charity must work in the same way as an ideal. Based on the values of lambda, it is possible to establish which fundraising practice of which organization is the most indicative for a particular outsider unit.

\section{Conclusions}

The results of calculating the relative efficiency of fundraising activities of 20 small charitable organizations of Ukraine in 2019 according to the DEA method demonstrated the presence of leading units in the sector: DMU1 (CO "CF "Kyiv"), DMU8 ("CO "Nechitaylo family foundation"), DMU10 CF "Blagomay"), DMU15 (CO "Berezani Community Foundation"), DMU16 (CO "CF "Hope for life"), DMU17 (ICF Dr. Bersenev), DMU19 (CO "CF "Community unity") and DMU20 (CO "WBF "Ray of hope"). The most cited leader was DMU15 (CO "Berezani Community Foundation"), whose fundraising activities can serve as a benchmark for most charitable micro-organizations - at a small cost (UAH 51435), it managed to raise UAH 84129 donations in 2019. For large charitable organizations, which are close to the average in terms of activity, such a benchmark is DMU1 (CO "CF "Kyiv"), the administrative and other maintenance costs of which are UAH 581895, while the results of fundraising activities exceed them by almost 10 times UAH 5696515. Using the work of volunteers allows the organization to carry out uninterrupted activities with only 2 employees in the state.

Comparison of outsiders with the standards allows us to draw a conclusion about the excess of their administrative costs at the specified amounts of funds raised in 2019. Often the budget of such expenses is formed not taking into account the real need to finance their own activities, but based on legal restrictions - no more than $20 \%$ of income in the current year. This value is used by many organizations as a benchmark for the redistribution of funds received in two areas: the provision of core activities (20\% of income) and charity (80\% of income).

Note that the model used to assess the financial efficiency of fundraising activities of charitable organizations of Ukraine has two significant limitations: 1) disregard for the environment and the specifics of the functioning of specific subjects of charity; 2) risks associated with the inaccuracy of information provided by charitable organizations in the Report on the use of income (profits) of a non-profit organization. Modernization of the proposed method of assessing the efficiency of fundraising activities taking into account the above factors will be the subject of our further research.

\section{References}

Basova, M. M. (2019). The main criteria for the effectiveness of fundraising in Russian NNO. Ekonomicheskie nauki. № 6 (175). 154-161. https://doi.org/10.14451/1.1751

Brooks, Arthur C. (2004). Evaluating the Effectiveness of Nonprofit Fundraising. The Policy Studies Journal. vol. 32. no. 3. 363-374. https://doi.org/10.1111/j.1541-0072.2004.00070.x

Buzduhan, Ya. M. (2011). Legal and economic factors of charitable efficiency. Viche. № 22. 12-15.

Data Envelopment Analysis: Theory, Methodology and Application by Abraham Charnes [et al] (1994), Springer, Netherlands.

Epstein, Marc J. and McFarlan, F.W. (2011). Measuring the Efficiency and Effectiveness of a Nonprofit's Performance. Strategic Finance. October. 27-34. 


\section{Management Theory and Studies for Rural Business and Infrastructure Development eISSN 2345-0355. 2021. Vol. 43. No. 1: 100-110 \\ Article DOI: https://doi.org/10.15544/mts.2021.09}

Fredriks, L. (2010). The Art of Asking for Money. How to ask anyone for any amount for any purpose. ZAO "Olimp-Biznes", Moscow, Russia.

Greenfield, James M. (2004). Fundraising Fundamentals: A Guide to Annual Giving for Professionals and Volunteers. John Wiley \& Sons, New York, USA.

Greenfield, James M. (1996). Fund-Raising Cost Effectiveness: A Self-Assessment Workbook. John Wiley \& Sons, New York, USA

Grishchenko, Iu. I. (2015). Development of fundraising in Russia. Nekommercheskie organizatcii v Rossii. № 1. $32-40$.

Help yourself: Ukrainians are disappointed in reforms, but ready to support each other and their communities, National Public Involvement Survey (October 2020). Available at: https://engage.org.ua/dopomozhy-sobi-sam-ukraintsirozcharovani-v-reformakh-ale-hotovi-pidtrymuvaty-odne-odnoho-ta-svoi-hromady/

Herman, Robert D. and Renz, David O. (2004). Doing Things Right: Effectiveness in Local Nonprofit Organizations, A Panel Study. Public Administration Review. vol. 64. no. 6. 694-704.

Hudz, A. O. (2019). Classification of forms and types of charitable activities in Ukraine. Problemy trudovoho prava ta prava sotsialnoho zabezpechennia. № 1. 61-64. https://doi.org/10.32850/sulj.2019.1-15

Levis, Wilson "Bill” and Williams, Cathlene (2011). How to Use AFP's Growth-in-Giving Reports to Improve Fundraising Performance. Advancing Philanthropy. March/april. 35-41.

Ometsinska, M. V. (2010). The current state of philanthropy and philanthropy in Ukraine: problems and prospects. Visnyk Natsionalnoi akademii kerivnykh kadriv kultury i mystetstv. № 3. 164-168.

Pasichnichenko, S. V. (2014). Charity as a social phenomenon and the basis for the formation of social assistance. Pravo i suspilstvo. № 1. 87-91.

Povstyn, O.V. (2014). Charity as a tool for implementing state social policy. Sustainable economic development. Stalyi rozvytok ekonomiky. № 2 (24). 26-33.

Rodchenko, V. B. and Serohina, D. O. (2014). Institutional aspects of charity development in Ukraine. Efektyvna ekonomika. № 12. Available at: http://www.economy.nayka.com.ua/?op=1\&z=3942

Serbyn, R. A. (2015). Theoretical and legal foundations of the concept of charity. Aktualni problemy derzhavy $i$ prava. vyp. $75.412-416$.

Taysir, Eyup A. and Taysir, Nurgul K. (2012). Measuring Effectiveness in Nonprofit Organizations: An Integration Effort. Journal of Transnational Management. vol. $17 . \quad$ no. $3.220-235$. https://doi.org/10.1080/15475778.2012.706736

Vysochan, O., Hyk, V. and Vysochan, O. (2020). Accounting support of financing IT-clusters activity in Ukraine. Management Theory and Studies for Rural Business and Infrastructure Development. 42 (4). $497-503$. https://doi.org/10.15544/mts.2020.51.

Yi, David T. (2010). Determinants of Fundraising Efficiency of Nonprofit Organizations: Evidence from US Public Charitable Organizations. Managerial and Decision Economics. vol. 31. 465-475. https://doi.org/10.1002/mde.1503

Copyright (C) 2021 Author(s), published by Vytautas Magnus University. This is an open access article distributed under the terms of the Creative Commons Attribution Non-Commercial 4.0 (CC BY-NC 4.0) license, which permits unrestricted use, distribution, and reproduction in any medium provided the original author and source are credited. The material cannot be used for commercial purposes. 